\title{
A Magyar Tudományos Akadémia és a Magyar Nemzeti Vidéki Hálózat együttmüködése keretében megvalósult komplex vidékkutatási programról
}

\section{A complex rural research program conducted by the Hungarian Academy of Sciences and the Hungarian National Rural Network - an introduction}

\author{
PERGER ÉVA
}

PERGER Éva: intézetigazgató, tudományos főmunkatárs, MTA Közgazdaság- és Regionális Tudományi Kutatóközpont, Regionális Kutatások Intézete, Kecskemét; perger.eva@rkk.hu

KULCSSZAVAK: vidéki tér, komplex vidékkutatási program

ABSZTRAKT: A vidéki tér megismeréséhez és a vidék fejlődését, értékeinek megőrzését segítő támogatási programok megalapozásához különböző tudományterületek módszertanát és eredményeit ötvöző komplex kutatásokra van szükség. A Magyar Nemzeti Vidéki Hálózat és a Magyar Tudományos Akadémia együttműködésén alapuló, 2012 végén indult komplex vidékkutatási program lehetőséget adott arra, hogy az MTA intézményhálózatának vidéki kutatóhelyein dolgozó és különböző szakterületeket képviselő kutatók - egyéb vidéki szakértők bevonásával - mintegy „virtuális” vidékkutatási hálózatot alkotva dolgozzanak. A kutatási program elsődleges célja a 2014-2020 közötti tervciklusra való felkészülés tudományos magalapozása volt, de számos elméleti, módszertani eredménnyel is szolgált, melyekből ízelítőt adnak a Tér és Társadalom e tematikus számában megjelenő tanulmányok. A bevezető célja, hogy áttekintést adjon a vidékkutatási program hátteréről, célkitűzéseiről, megvalósításáról, felvillantsa annak egyéb eredményeit és az eredmények eddigi hasznosulását.

Éva PERGER: director, senior research fellow, Institute for Regional Studies, Research Centre for Economic and Regional Studies, Hungarian Academy of Sciences, Kecskemét; perger.eva@rkk.hu

KEYWORDS: rural space, complex rural research program

ABSTRACT: A multidisciplinary approach is essential for understanding rural transformation processes and providing a theoretical background for the programmes supporting rural development and the preservation of rural values. The joint rural research programme of the Hungarian Academy of Sciences and the Hungarian National Rural Network, started at the end of 2012, created a unique opportunity for researchers and experts with various fields of interest working in different rural locations to collaborate and form a temporary rural research network. Although the primary goal of the research was to provide a scientific background for the preparation of the 2014-2020 EU programming period, its results also included various theoretical

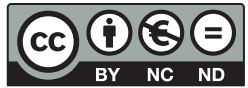


and methodological findings; some of them are presented in this thematic issue of Space and Society. The aim of this introduction is to give an overview of the background, main goals and implementation of this rural research programme, to outline its main findings and the application of the results.

\section{Bevezetés}

A magyar regionális tudomány hagyományosan kiemelt kutatási területe a vidéki tér környezeti, gazdasági, társadalmi átalakulásának vizsgálata. Az éghajlatváltozás hatásai, a környezeti fenntarthatóság, az energiabiztonság kérdései, a víz és az élelmiszer stratégiai termékké válása, a foglalkoztatás problémái, a helyi közösségek felbomlásának negatív társadalmi hatásai, a szegénység térnyerése, az átalakuló város-vidék viszonyok, a centrumok és perifériák között feszülő társadalmi, politikai ellentmondások európai szinten is fokozottan ráirányítják a figyelmet a vidéki térségekre. A vidéki tér megismeréséhez és a vidék fejlődését, értékeinek megőrzését segítő támogatási programok érdemi megalapozásához hazánkban is különböző tudományterületek módszertanát és eredményeit ötvöző komplex kutatásokra lenne szükség. Olyan inter- és multidiszciplináris kutatásokra, melyekben - a fejlettebb országok gyakorlatához hasonulva - szociológusok, falu- és agrárföldrajzosok, ökológusok, az agrártudományok, a közgazdaságtan és a regionális tudomány képviselői együttmüködve tárják fel a vidéki térségek környezeti, gazdasági, társadalmi összefüggéseit. Ilyen típusú együttmüködésre adott szervezeti és pénzügyi keretet az a Magyar Nemzeti Vidéki Hálózat és a Magyar Tudományos Akadémia együttműködésén alapuló komplex vidékkutatási program, melynek néhány - a folyóirat arculatához illeszkedő - eredményét a Tér és Társadalom e számának tanulmányai mutatják be. Bevezetőm célja, hogy áttekintést adjak a kutatási program hátteréről, célkitűzéseiről, megvalósításáról, felvillantsam annak egyéb eredményeit és az eredmények eddigi hasznosulását.

\section{A kutatás háttere}

A Magyar Nemzeti Vidéki Hálózat (MNVH) elnöke az elnökség által elfogadott cselekvési tervhez (2012-2014) kapcsolódóan kereste meg a Magyar Tudományos Akadémia (MTA) elnökét 2012 júniusának végén. Levelében felhívta a figyelmet arra, hogy hazánkban - bár a kapacitások az MTA hálózatában szétszórva rendelkezésre állnak - hiányoznak a vidékstratégia megalapozásához elengedhetetlen, komplex szemléletủ agrár- és vidékfejlesztési kutatások szervezeti és pénzügyi keretei. Egy olyan megállapodásra tett javaslatot, mely alapján az MTA vidéki telephelyű kutatóbázisainak meglévő kapacitásait a vi- 
dék igényes és hiteles tudományos megismerésére, a nemzetközi és hazai vidéktudományos és tervezési-fejlesztési ismeretek bővítésére, terjesztésére fordíthatná. A javaslat megvalósításának első lépése az MNVH felkérése alapján egy olyan komplex program végrehajtása volt, melyben az MTA érintett kutatóközpontjainak - főként vidéki - tudományos műhelyei mintegy virtuális vidékkutatási intézetet alkotva közösen dolgoztak.

A program érdemi kutatásai 2012 decemberében indultak és 2013 végén fejeződtek be. Koordinációját a széles körü vidéki hálózattal rendelkező MTA Közgazdaság- és Regionális Tudományi Kutatóközpont (MTA KRTK), illetve annak tudományos intézete, a Regionális Kutatások Intézete (RKI) látta el. Az intézményes formában bevont MTA-intézetek a KRTK tudományos egységein kívül az MTA Ökológiai Kutatóközpont, valamint az MTA Agrártudományi Kutatóközpont Talajtani és Agrokémiai Intézete voltak.

A program során alapvetően az eredeti terveknek megfelelően valósult meg 6 komplex kutatási projekt és 7 kisebb célprojekt. E projektek építettek az MTA vidékkutatásokkal foglalkozó tudományos műhelyeinek tapasztalataira, és javaslataikkal a következő tervidőszakra szóló vidékfejlesztési program tervezésének és végrehajtásának tudományos megalapozását szolgálták. A kutatások amellett, hogy széleskörűen felmérték a hazai sajátosságokat, közvetlenül kapcsolódtak az európai szinten megfogalmazott vidékfejlesztési célokhoz, illetve a nemzeti vidékfejlesztési program végrehajtásának várható kereteihez. A legtöbb esetben ezeket a sajátosságokat nem csupán az irodalom- és dokumentumelemzés vagy a statisztikai adatfeldolgozás módszereivel tárták fel, hanem empirikus vizsgálatokkal - esettanulmányokkal, mélyinterjúkkal, kérdőíves lekérdezéssel - is. A vidéki tudományos műhelyek miközben egy-egy átfogó kutatási projektet vezettek és térségük jellemzőinek feltárásával segítették a vidékfejlesztés differenciált megközelítését, helyi konzultációkkal, workshopokkal, konferenciákkal erősítették helyi tudományos közéleti szerepüket. A program keretében a különböző - eddig többnyire elkülönülten működő - tudományos egységek szervezett módon megosztották egymással tudományos eredményeiket, bevonták egymást a projektek végrehajtásába.

A programban összesen 29 tudományos tanulmány, 10 résztanulmány, 24 esettanulmány, 1 szakbibliográfia, 5 adatbázis, 1 webes adatpublikáció és 21 térkép készült. A kutatási feladatokat döntően a felkért intézetek kutatói végezték, de személyes közremüködőként számos más - főleg vidéken dolgozó - kutató, egyetemi oktató és szakértő is részt vett a projektek végrehajtásában. Megvalósult egy igen széles körű együttmüködés a bevont kutatóhelyek - mind az adott intézetek különböző kutatócsoportjai, mind maguk az intézetek - között, sőt vidéki egyetemek, főiskolák oktatói és más szakemberek is csatlakoztak ehhez a „virtuális hálózathoz”. A terepmunkák helyszínei szinte lefedték az ország vidéki térségeit. ${ }^{1} \mathrm{~A}$ kérdőíves lekérdezések és mélyinterjúk több száz érintettet vontak be az ország minden tájáról. A konzultációk, workshopok és konferenciák helyszínei szintén az ország különböző vidéki térségeiben találhatók. ${ }^{2}$ A kutatás 
során így lehetőség nyílt arra, hogy a vidékfejlesztésben érdekeltek a vidéki helyszíneken kapcsolódjanak be a munkába, és észrevételeikkel, javaslataikkal segítsék a kutatásokat. A kutatási eredmények mellett a komplex vidékkutatási program fontos eredménye az is, hogy végrehajtása során mind szervezeti, mind személyi értelemben kialakult egy olyan kutatói-szakértői hálózat, mely alkalmas lehet arra, hogy továbbra is eredményesen járuljon hozzá a magyar vidék tudományos megismeréséhez és fejlődéséhez.

\section{A program tudományos eredményei}

A komplex vidékkutatási program projektjei olyan fontos aspektusait vizsgálták a vidékkel kapcsolatos kérdéseknek, melyek hangsúlyozott jelentőséget kapnak a 2014-2020 közötti uniós tervciklusban.

Az európai fejlesztéspolitika hangsúlyos elemévé válik a lokalitás szerepének újraértelmezése, a vidéki térségekben rejlő potenciálok lehető legjobb kihasználása. E filozófia jegyében külön projekt értékelte a magyar vidéki térségek helyzetét az európai térben, vizsgálta meg a vidék differenciálódásának hazai folyamatait, tárta fel a vidéki térségek lehetséges típusait és eltérő fejlesztési igényeit. Szándékunk az volt, hogy tudományos hátteret nyújtsunk olyan, a „lokalitásra épülő” vidékfejlesztési politika alapjainak megteremtéséhez, mely a magyar sajátosságokhoz illeszkedően értelmezi az európai trendeket, így alkalmas arra, hogy kezelje a speciálisan magyar vidéki problémákat. Munkánk során elméleti és gyakorlati megfontolások alapján kétféle javaslatot tettünk a vidéki térségek újfajta lehatárolására, az egyik a járási szintet tekintette alapegységnek, a másik - a központi tervezési folyamathoz alkalmazkodóan - a települési szintet. Ezt követően a vidéki térségek differenciálódása szempontjából legfontosabbnak ítélt jellemzők alapján a vidékinek tekinthető járásokat hazai sajátosságainkhoz illeszkedően tipizáltuk. A kialakított térségtípusok elemzésével és összehasonlító vizsgálatával, valamint kilenc mintatérségben készült esettanulmány alapján készültek javaslatok a hazai sajátosságokhoz illeszkedo", helyi igényeket figyelembe vevo", térségi alapon szerveződo", differenciált vidékfejlesztés megalapozásához. A projekt legmeglepőbb eredménye az volt, hogy vidéki térségeink differenciálódása nem oly erőteljes, mint ahogy azt feltételezzük. Jellemzőik, problémáik, sőt fejlesztési céljaik többsége nem helyspecifikus, és nem is igazán megoldható a vidékfejlesztési program keretei között. A kutatás így gyakorlatilag nem igazolta azt a hipotézist, hogy hazánkban a térségi alapon differenciált vidékfejlesztés ideje jött el. A helyi „területi tőke” legfontosabb eleme úgy tűnik, hogy ma is a földrajzi elhelyezkedés. A vidéki térségek szinte mindegyikében jelenleg és különösen hosszú távon a legnagyobb problémát a humán szféra kapacitásainak kimerülése és a „helyben maradó” pénzügyi tőke hiánya okozza. Az alulról építkező, helyi erőforrásokra építő fejlesztések csak korlátozott sikereket hoztak. Fontos lenne ezért, hogy az országos ágazati programok fokozot- 
tabban vegyék figyelembe a vidéki térségek sajátosságait, illetve hogy a pályázati kiírások tartalmazzanak olyan elemeket, melyek a speciális vidéki problémákra koncentrálnak. A továbblépéshez elengedhetetlen az is, hogy a helyi szereplők megerősödjenek, a helyi tervezési gyakorlat és együttműködési kultúra javuljon. A helyi kezdeményezéseken alapuló térségfejlesztés súlyát és szerepét ezért egyértelmüen növelni kellene.

Már e projektünk is foglalkozott azzal, hogy az esettanulmányok helyszíneként szolgáló vidéki járásokban hogyan értékelik az elmúlt időszak uniós támogatásainak felhasználását. A projektalapú megközelítés és a bürokratikus eljárások a tapasztalatok szerint gyakran visszavetik a helyi kreativitást és innovációt. Nincs igazán érdemi különbség a helyi tervekben, javasolt fejlesztésekben, és gyakoriak az ad hoc, az éppen aktuális pályázatokhoz igazodó fejlesztési megoldások. Települési szintủ sikereket ugyan találtunk, de térségi szinten szinte egyáltalán nem tapasztaltunk egyértelmű eredményeket az uniós források felhasználásában. A valós együttműködés a települések, illetve a különböző fejlesztési szereplők között igen ritka. Különösen súlyos probléma, hogy a vidéki térségek központjai, a kis- és középvárosok nem képesek betölteni területszervezési szerepüket. A „városi” és a „vidéki” tervek és fejlesztések gyakran „elmennek egymás mellett”. Ezt a jelenséget pedig csak erősítette a „regionális fejlesztés” és a „vidékfejlesztés” kettőssége. Egy másik projektünk tisztán ökonometriai megközelítéssel azt mutatta ki, hogy az uniós programok hatása vidéki térségeinkben valószínűsíthetően sok kívánnivalót hagy maga után. Egy speciális „,szeletét” fedi le a lokalitásra épülo” megközelítés alkalmazásának a „közösségvezérelt helyi fejlesztés” (CLLD) és a „multifund” tervezés eszköze, melyek hazai fejlesztéspolitikai alkalmazhatóságát vizsgálta egy másik projektünk, kitérve a CLLD hazai javasolt területi léptékére, illetve a részvételen alapuló tervezés módszertani ajánlásaira.

A 2014-2020-as tervciklus vidékfejlesztési céljai között kiemelten szerepel a környezeti állapot megőrzése, javítása, valamint az éghajlatváltozáshoz történő alkalmazkodás. Ennek megfelelően öt projektünk lényegében a vidéki térségek környezeti kérdéseire koncentrált. Külön kiemelendő, hogy e kutatások nem csupán a szük értelemben vett környezeti kérdésekkel foglalkoztak, hanem a környezet és a gazdaság, a környezet és a társadalom összefüggéseit is vizsgálták. A projektek a környezet állapotának, az eddigi fejlesztési és gazdálkodási gyakorlat hatásainak (a talajra, biodiverzitásra, tájhasználatra), valamint a klímaváltozásból eredő várható hatásoknak az elemzése mellett ajánlásokat tettek a következő tervciklusban szükséges intézkedésekre, továbbá módszertanokat dolgoztak ki az új tervciklus programjainak megvalósítására, hatásainak nyomon követésére. Az agrár-környezetgazdálkodási célprogram kidolgozásához és megvalósításához kapcsolódott az új célprogrami támogatások területi kijelölésének meghatározására, a program biológiai sokféleségre gyakorolt hatásának monitorozására készült módszertan. A kutatási program keretei között kidolgozott „zöld pont rendszer” a gazdaságok ökoló- 
giai, környezeti teljesítményeinek a kimutatására alkalmas, amely akár egy jövőbeni támogatási rendszer alapjait is képezheti. Az éghajlatváltozással foglalkozó projektünk ajánlásokat fogalmazott meg az agrártámogatások és a vidékfejlesztési politika eszközeinek olyan finomhangolására, mely segítheti a megfelelő adaptációt.

A társadalmi befogadás előmozdítása, a szegénység csökkentése és a gazdasági fejlődés támogatása a vidéki térségekben szintén kiemelt cél. Ehhez a programban két altéma kapcsolódott, amelyek széles körü empirikus kutatásokra alapozva adtak képet a szegénység hazai állapotáról, okairól, területi jellemzőiről és e problémák kezelésének lehetőségeiről. A vidékiségből adódó marginalizálódás társadalmi, gazdasági, települési, térségi összetevőit, konfliktusait, okait és a feloldás, kezelés lehetőségeit vizsgáló projekt azt állapította meg, hogy a jelenleg marginálisként azonosítható terek számára kínált fejlesztési irányok nem vezethetnek el a kívánatos célokhoz és a jelenlegi versenyorientált program- és projektlogikában csak tartóssá tehetik a marginális helyzetet. Miután a térségek nem egyveretűek, egyszerre több kategóriába is beletartoznak, a kínált fejlesztési stratégiai irányok számos ponton egymást oltják ki. A fejlesztési dokumentumokban azonosított erőforrások a térségi gazdasági szereplők szerint alapvetően nem állnak rendelkezésre a térségekben és/vagy a pozitív példák nem jutnak el a gazdasági szereplők szélesebb köreihez, így hatásuk pontszerủen jelentkezik és továbbgyưrűző hatást nem lehet kimutatni. A megoldás kulcsa a tervezési logika megfordítása volna térségi szinten, vagyis a nemcsak látszólagosan, hanem valódi módon alulról építkező (bottom-up), a helyi kulcsszereplők véleményét messzemenőkig figyelembe vevő tervdokumentumok elkészítése. A szegénység mérséklését szolgáló szakpolitikai beavatkozások tapasztalatait elemző másik kutatásunk azokra a problémákra mutatott rá, amelyek a szegénység mérséklését szolgáló projektek megvalósítását és fenntarthatóságát, valamint társadalmi hasznosulását nehezítik, illetve akadályozzák. A legsúlyosabb gondot az jelenti, hogy a szegénység nem homogén létállapot, és különösen a mélyszegénység olyan összetett és súlyos probléma, amely hosszú időtávra tekintő komplex programokat, beavatkozásokat igényel, így nem oldható meg a projekteket jellemző rövid időtávon és az indikátorok teljesítésére törekvő, óhatatlanul is lefölözéshez vezető szemlélettel, gyakorlattal.

A tudásátadás és az innováció előmozdítása a vidéki térségekben szintén kiemelt uniós vidékfejlesztési cél. Egyik projektünk témája ezért vidéki térségeink társadalmi és gazdasági innovációt befogadó képességének vizsgálata volt. E kutatás is széles körű empirikus felmérésre alapozott, összeállítva egy hazai „innovációs” katasztert. A kutatás legfontosabb megállapítása talán az, hogy az újdonságok és újitások bevezetése a vidéki térségeinkben nem ritka, mind a társadalmi, mind a gazdasági innováció elemei, esetei megtalálhatók. Ráadásul az „innovációs térképet” nem jellemzi az a fajta kelet-nyugati lejto, ami általában a gazdasági fejlettséget bemutató térképeinket. Jelen van az innováció leg- 
rosszabb helyzetű térségeinkben is, csak az országos közpolitikának rá kell segíteni, hogy e kezdeményezések érvényesülhessenek, valós eredményre vezessenek a térségek fejlődésében.

A rövid ellátási láncok kérdése mind a hazai, mind az uniós vidékstratégia meghatározó eleme. Ehhez kapcsolódó célprojektünk az élelmiszerláncok müködésének hatékonyságát, a kereskedelmi árrések alakulását és azok okait vertikális ártranszmisszió-elemzés segítségével vizsgálta, valamint empirikus módszerekkel tárta fel a rövid élelmiszerláncok működésének sajátosságait és lehetőségeit a hazai körülmények között.

\section{Az eredmények disszeminációja}

A komplex vidékkutatás egyes részeredményeit már a program végrehajtásának időszakában több szakmai és ismeretterjesztő fórumon ismertettük. Először a 2013. április 10-én a Vajdahunyadvárban rendezett konferencián kaptunk lehetőséget arra, hogy a programot és első munkaanyagait bemutassuk az MNVH tagjainak, a szélesebb szakmai közönségnek. A kutatásainkban részt vevő szakemberek - meghívás alapján - több esetben közvetlenül is elmondhatták tapasztalataikat, véleményüket olyan szakmai megbeszéléseken, melyek az uniós forrásokból finanszírozott vidékfejlesztési program kidolgozását segítették. A szélesebb vidéki szakmai közönség tájékoztatása érdekében kutatóink megjelentek számos MNVH-s, illetve kormányzati szervek által szervezett vidéki rendezvényen. A program tudományos eredményeinek egyes aspektusairól kutatóink külföldi és hazai tudományos konferenciákon tartottak előadásokat. ${ }^{3}$ A III. Vidékfejlesztési Napon 2013. decemberben a szekcióülések témájához kapcsolódó bevezető előadásokat szintén a programban részt vevő szakértők adták.

2014. június 24-én Kecskeméten A vidékfejlesztés jelene és jövője címmel széles körü érdeklődés mellett tartottuk a kutatási program záró műhelykonferenciáját, ami arra is alkalmat adott, hogy a résztvevők véleményeket, javaslatokat fogalmazzanak meg és megvitassák a felmerülő kérdéseket. A falu című folyóirat 2014. nyári különszámában és részben őszi számában olyan cikkek kaptak helyet, amelyek a kutatások közvetlen aktualitással rendelkező vagy gyakorlati relevanciájú részeredményeit mutatják be. A programban elkészült tanulmányok alapján készült el a vidék megismerését elsősorban ismeretterjesztési, oktatási célokkal szolgáló Tudáskészlet a magyar vidék fejlesztéséhez címü - a NAKVI kiadásában megjelent - sorozat első tíz füzete. Bár a kutatási program alapvetően alkalmazott kutatási célokat szolgált, a résztvevők nagy hangsúlyt fektettek a kutatások elméleti megalapozásra, új módszertani megoldások keresésére, illetve az összegyüjtött adatok, információk további alapkutatási jellegü feldolgozására. A Tér és Társadalom című folyóirat e számában közölt tanulmányok ezekből az eredményekből adnak ízelítőt. 
A komplex vidékkutatási program keretében készült tanulmányok, esettanulmányok, térképek, adatbázisok teljes terjedelmükben elérhetők az MNVH honlapján az Átfogó vidékkutatási program (http://www.mnvh.eu/node/591359) menüpont alatt.

\section{Jegyzetek}

1 A Balassagyarmati, Jánoshalmi, Lenti, Mezőkövesdi, Kisbéri, Sátoraljaújhelyi, Dabasi, Szarvasi járások, a Fehérgyarmati, Bonyhádi, Encsi, Sarkadi, Mezőkovácsházi, Sárospataki és Lengyeltóti kistérség, valamint Belecska, Kisvejke, Lengyel, Závod, Katymár, Tamási, Dombóvár, Balkány, Berettyóújfalu, Lipót, Hövej, Rozsály, Zajta, Dunasziget települések.

2 Békéscsaba, Sarkad, Sárospatak, Mezőkovácsháza, Lengyeltóti, Kecskemét, Győr, Győrzámoly, Bakonyszombathely, Bögöte, Pécs, Edelény, Dabas, Szarvas, Kisbér, Sátoraljaújhely, Budapest.

3 A hazai rendezvények közül kiemelendő a V. Alföld Konferencia (Békéscsaba) 2013. november 7-én, a külföldi rendezvények közül a Warsaw Regional Forum 2013 októberében, melynek témája a Territorial capital: concepts, indicators and policy volt. 